\title{
Clinical and molecular characterization of patients with classic $3 \beta$-hydroxysteroid dehydrogenase deficiency
}

\author{
Pattara Wiromrat ${ }^{1 *}$, Kewalee Unajak ${ }^{2}$, Viral Shah ${ }^{3}$, Taninee Sahakitrungruang ${ }^{1}$ \\ From 8th APPES Biennial Scientific Meeting \\ Darwin, Australia. 29 October - 1 November 2014
}

\section{Background}

$3 \beta$-hydroxysteroid dehydrogenase type 2 (3ßHSD2) is the key enzyme converting $\Delta 5$-steroids to $\Delta 4$-ketosteroids in adrenal and gonadal steroidogenesis. Severe lossof-function mutations of HSD3B2 gene encoding for this enzyme cause the rare form of congenital adrenal hyperplasia, "3 $\beta$ HSD deficiency". Affected individuals have salt losing, adrenal insufficiency and ambiguous genitalia in both sexes. Patients with $3 \beta$ HSD deficiency may have elevated $17 \alpha$-hydroxyprogesterone (17OHP) levels due to normal peripheral type $1,3 \beta \mathrm{HSD}$.

\section{Aims}

To describe two unrelated patients with $3 \beta$-hydroxysteroid dehydrogenase deficiency and perform mutation analysis of the HSD3B2 gene.

\section{Patients and Methods}

Patient 1 (Thai) and 2 (Indian) are 46,XY male newborns with ambiguous genitalia (micropenis, penoscrotal hypospadias) who developed salt-losing since early infancy. They were stabilized with normal saline resuscitation and high dose hydrocortisone replacement. Patient 2 was initially misdiagnosed as 21-hydroxylase deficiency due to elevated 17OHP until he was referred for genitoplasty at the age of 2.5 years and the patient were re-evaluated. The ACTH tests revealed low cortisol response, moderately elevated $17 \mathrm{OHP}$, elevated $\Delta^{5} / \Delta^{4}$ steroids, suggestive of blockage at the level of enzyme 3ßHSD. Patients' leukocyte genomic DNA was extracted and the entire coding regions of the HSD3B2 gene were assessed by polymerase chain reaction (PCR) and sequencing analysis.

\section{Results}

Patient 1 was homozygous for T259M (c.776C $>$ T) mutation in the HSD3B2 gene. Patient 2 was homozygous for the novel nonsense mutation $\mathrm{Y} 180 \mathrm{X}(\mathrm{c} .540 \mathrm{C}>\mathrm{A})$ and his parents were heterozygous carrier.

\section{Conclusion}

We report the mutations of HSD3B2 gene, T259M and Y180X (novel) responsible for classic 3ßHSD deficiency. The clinical and hormonal phenotypes can be complicated in this disorder. These cases emphasize the importance of confirming the specific enzyme deficiency with molecular genetic analysis.

Written informed consent was obtained from the patient for publication of this abstract and any accompanying images. A copy of the written consent is available for review by the Editor of this journal.

\section{Authors' details}

${ }^{1}$ Chulalongkorn University, Bangkok, Thailand. ${ }^{2}$ Chiang Mai University, Chiang Mai, Thailand. ${ }^{3}$ Government medical college, Bhavnagar, Gujarat, India.

Published: 28 April 2015

doi:10.1186/1687-9856-2015-S1-P43

Cite this article as: Wiromrat et al:: Clinical and molecular characterization of patients with classic $3 \beta$-hydroxysteroid dehydrogenase deficiency. International Journal of Pediatric Endocrinology 2015 2015(Suppl 1):P43.

${ }^{1}$ Chulalongkorn University, Bangkok, Thailand

Full list of author information is available at the end of the article 